\title{
Studies on the release of gonadotrophins during the superfusion of isolated rat pituitaries in a continuous flow system
}

\author{
M. J. Kilpatrick, W. P. Collins and J. R. Newton \\ W.H.O. Collaborating Centre for Clinical Research on Human Reproduction, \\ and Department of Obstetrics and Gynaecology, King's College Hospital Medical School, \\ Denmark Hill, London SE5 8RX, U.K.
}

\begin{abstract}
Summary. A continuous flow system has been developed to study the endocrine functions of isolated organs. The procedure has been used to investigate the effect of a synthetic gonadotrophin-releasing hormone (Gn-RH) upon the anterior pituitary gland of the adult male rat. A Radiometer blood gas/pH analyser was used to monitor the $\mathrm{pH}$ and partial pressures of oxygen and carbon dioxide in the perfusion medium. A series of six experiments with four pituitaries per flask established that the rate of gonadotrophin release under basal conditions was $646 \pm 301$ (S.D.) $\mathrm{ng} \mathrm{LH} / \mathrm{ml}$ and $404 \pm 124$ (S.D.) $\mathrm{ng}$ FSH/ml. The duration and intensity of the response to Gn-RH was assessed by measuring the areas under the curves according to the trapezoidal rule. A significant increase in the release of FSH and $\mathrm{LH}$ was obtained by the administration of $250 \mathrm{ng} \mathrm{Gn-RH/ml} \mathrm{medium,} \mathrm{and} \mathrm{dose-response} \mathrm{curves} \mathrm{were} \mathrm{produced} \mathrm{for}$ up to $10 \mu \mathrm{g} / \mathrm{ml}$.
\end{abstract}

\section{Introduction}

The ability of synthetic gonadotrophin-releasing hormone (Gn-RH) to release LH and FSH from the rat anterior pituitary has been demonstrated under a variety of experimental conditions (Schally et al., 1972; Makino, 1973; Ondo et al., 1973). There is still, however, a lack of detail regarding the biochemical mechanisms by which this release may be affected. Studies that have involved the administration of synthetic Gn-RH by infusion into the systemic or hypophysial portal blood system have provided useful information, but suffer from the limitation that the results are inffuenced by many factors, including the feedback of gonadotrophins and steroids upon the hypothalamicpituitary complex.

An alternative approach has been to study the effect of $\mathrm{Gn}-\mathrm{RH}$ on the release of gonadotrophins from the isolated anterior pituitary maintained in a static medium. This procedural format, however, has the inherent problem that it allows the accumulation of metabolic products and their possible feedback effects. Accordingly, more recent developments have involved the adaptation of a superfusion system that was first devised for studies on the adrenal cortex by Tait et al. (1967), and subsequently applied to limited studies on anterior pituitary tissue from the rat (Serra \& Midgley, 1970), quail (Smith \& Follett, 1971) and cow (Zolman \& Convey, 1972).

The present communication is concerned with a detailed description and evaluation of specialized equipment for the superfusion of rat pituitaries in a continuous flow system. In addition, results are presented which show that the administration of graded doses of Gn-RH produce well-defined, reproducible dose-response curves in terms of the release of LH and FSH, which should serve as a basis for subsequent studies on the mechanism of action of the releasing hormone.

\section{Materials and Methods}

\section{Preparation of pituitaries}

The animals used were male Wistar Rats weighing over $200 \mathrm{~g}$. The rats were killed by decapitation and the pituitaries removed. On every occasion the removal of the pituitaries was completed between 
09.30 and 10.00 hours. The pars posterior and median eminence were dissected away and discarded, and the remaining portion (pars anterior) was placed in the flow chamber. Four pituitaries per flask were used routinely in this study.

\section{Continuous flow apparatus}

The system was essentially the same as that described by Serra \& Midgley (1970), but differed in the following aspects. The incubation flasks (Text-fig. 1) were made of perspex, and consisted of two identical halves that when bolted together formed a water-tight inner recess which contained a small perspex disc. This disc had four holes ( $4 \mathrm{~mm}$ in diameter and $4 \mathrm{~mm}$ deep) which retained the pituitary tissue. The number of tissues used in each flask can be easily modified by using a disc with a corresponding number of holes. A stainless-steel gauze support was placed on each side of the disc (mesh count 325, plain weave: R. Cadish \& Sons, London). The inlet and outlet port of each flask was a female Luer fitting to which the infusion lines (Disposable Manometer Lines, Portex Ltd, Hythe, Kent) were connected. A three-way tap was incorporated into the infusion line in order to facilitate changes of medium or the administration of potentially active compounds. After assembly and connection, the incubation flasks were immersed in a water bath at $37^{\circ} \mathrm{C}$.

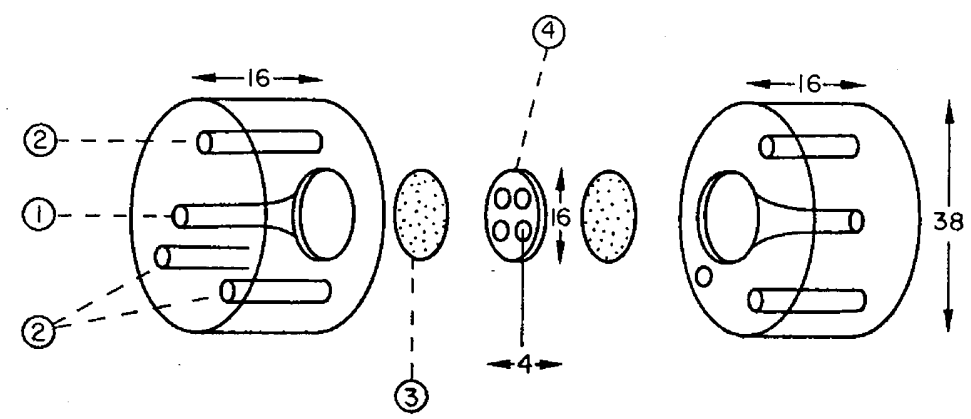

Text-fig. 1. Schematic drawing with dimensions (mm) of the perspex incubation flasks used to retain the anterior pituitaries during the course of the infusion. (1) Luer fitting for connection to the infusion lines; (2) holes to enable the halves to be bolted together; (3) stainless-steel gauze support disc; (4) tissue-retaining inner disc with holes for four pituitaries.

A multichannel peristaltic pump (Gilson Minipuls II, Anachem Ltd, Luton) was used to maintain the flow of medium through the system at a rate of $250 \mu \mathrm{l} / \mathrm{min} / \mathrm{flask}$ and an automatic fraction collector (Ultrorac 7000, LKB Instruments, Croydon, Surrey) was set to collect samples every 8 $\min (\equiv 2 \mathrm{ml}$ infusate). The infusion medium was Krebs-Ringer bicarbonate buffer with $0.2 \%(\mathrm{w} / \mathrm{v})$ glucose (KRBG).

A preliminary series of experiments was performed using a Radiometer blood gas $/ \mathrm{pH}$ analyser (V. A. Howe \& Co. Ltd, London, S.W.6), to establish the partial pressures of oxygen and carbon dioxide and the $\mathrm{pH}$ of the medium before and after passage through the system. It was found that vigorous gassing with $\mathrm{O}_{2}: \mathrm{CO}_{2}(95: 5 \mathrm{v} / \mathrm{v})$ supersaturated the medium with $\mathrm{O}_{2}(600 \mathrm{mmHg})$ and $\mathrm{CO}_{2}(35 \mathrm{mmHg})$ and maintained the $\mathrm{pH}$ at $7 \cdot 4$, with the medium equilibrated at $37^{\circ} \mathrm{C}$. Measurement of the same parameters after the medium had passed through the system gave the levels of $\mathrm{PO}_{2}$ as $200 \mathrm{mmHg}$ and the $\mathrm{PCO}_{2}$ as $35 \mathrm{mmHg}$, the $\mathrm{pH}$ remained stable at $7 \cdot 4$. These figures show the gas tensions in the medium to be suitable, as the $\mathrm{PO}_{2}$ in fresh rat blood is approximately $60 \mathrm{mmHg}$ and the $\mathrm{PCO}_{2}$ is about $30 \mathrm{mmHg}$, with a $\mathrm{pH}$ of $7 \cdot 4$.

The administration of a trace dose of ${ }^{125} \mathrm{I}$ at the three-way tap, and the subsequent collection and counting of the samples, established a clearance time of $5 \mathrm{~min}$ for the system. Consequently, after starting infusion of Gn-RH, the next collection tube to be completed was designated as time 0 min. The pituitaries were infused with KRBG for about $1.5 \mathrm{hr}$ before the administration of releasing hormone. This preincubation period has been previously demonstrated as sufficient to allow the 
pituitary tissue to equilibrate in the system and maintain a relatively constant basal release of gonadotrophins.

\section{Gonadotrophin hormone-releasing hormone}

Solutions of Gn-RH (Hoechst Pharmaceuticals 471, or I.C.I. 88,262) were prepared in KRBG buffer, and equilibrated with $\mathrm{O}_{2}: \mathrm{CO}_{2}(95: 5 \mathrm{v} / \mathrm{v})$ at $37^{\circ} \mathrm{C}$. Selected doses $(250 \mathrm{ng}, 500 \mathrm{ng}, 1000 \mathrm{ng}$ and $10 \mu \mathrm{g} / \mathrm{ml}$ ) were infused in a variable order, for a minimum period of $40 \mathrm{~min}$. An interval of 40 or $48 \mathrm{~min}$ was allowed between each administration.

\section{Sample collection and assay}

All samples were frozen at $-20^{\circ} \mathrm{C}$ after collection. $\mathrm{LH}$ and FSH were measured by radioimmunoassay. A $200 \mu \mathrm{l}$ aliquot of the sample was taken for the determination of $\mathrm{LH}$ and a $100 \mu \mathrm{l}$ aliquot for FSH; all samples were assayed in duplicate. The sample volume in the tube was adjusted to $400 \mu \mathrm{l}$ in each case using phosphate-buffered saline (PBS), pH 7.4, containing $1 \%(\mathrm{w} / \mathrm{v})$ bovine serum albumin (Fraction V, Sigma London Chemical Co. Ltd). The appropriate antigens (NIAMDDRat-LH-1-3 and -Rat-FSH-1-3) were labelled with ${ }^{125}$ I using a modification of the Chloramine T method (Hunter \& Greenwood, 1962). A $100 \mu \mathrm{l}(\simeq 20,000 \mathrm{ct} / \mathrm{min})$ aliquot of labelled antigen was added to all tubes. The LH and FSH content were assayed using the NIAMDD-Anti-Rat-LH-S1 and -Anti-Rat-FSH-S6 antisera respectively. Separation of antibody bound from free radioactivity was performed using a double-antibody method. A 1:120 (v/v) solution of donkey anti-rabbit precipitating serum (RD 17, Wellcome Reagents Ltd, Beckenham) and 0.05 M-EDTA/PBS, pH 7.4, was prepared, containing 1:1200 (v/v) of non-immune normal rabbit serum (TC 69, Wellcome Reagents Ltd). A $200 \mu \mathrm{l}$ aliquot of this solution was added to all tubes, except those used to determine the total radioactivity. After incubation and centrifugation $\left(2000 \mathrm{~g}, 20 \mathrm{~min}, 4^{\circ} \mathrm{C}\right)$, the supernatant was decanted, and the tubes allowed to drain for $2 \mathrm{hr}$ at room temperature. The radioactivity was then determined in an automatic $\gamma$-counter. The reference preparations were NIAMDD LH-RP-1 for LH, and FSH-RP-1 for FSH. The results were expressed as ng of the respective standards $/ \mathrm{ml}$ of infusion medium.

\section{Results}

\section{Evaluation of the radioimmunoassays}

There was no significant cross-reaction of the antisera with either Gn-RH or the medium before infusion. Further evidence for specificity was obtained from the degree of parallelism between the standard curves of the respective hormones and serial dilutions of the medium after the tissue had been perfused.

The limits of sensitivity for the methods were defined as twice the standard deviation obtained from the measurement in triplicate of the total amount of radioactivity bound to antibodies in the absence of unlabelled material. The intra-assay variation was assessed by the analysis in duplicate of 50 samples of medium after the tissue had been perfused, and the inter-assay variation by replicate analysis of one sample over the course of 12 assays. These results are shown in Table 1 . The range of values obtained for the determination of known amounts of hormone $(100,200$ and $400 \mathrm{ng} / \mathrm{ml})$ added to previously assayed fractions of the perfusate were within the intra-assay variation.

\section{Basal release of $L H$ and FSH}

The concentrations of gonadotrophin released into the medium during the period of the incubation were determined. The range of values was $646 \pm 301$ (S.D.) $\mathrm{ng} \mathrm{LH} / \mathrm{ml}$, and $404 \pm 124$ (S.D.) ng $\mathrm{FSH} / \mathrm{ml}$. The overall mean, and the mean deviation from the mean, for both gonadotrophins during six infusions of KRBG over a 4-5 hr period can be seen in Text-fig. 2. 
Table 1. Evaluation of the radioimmunoassay methods for (a) $\mathrm{LH}$ and (b) FSH

\begin{tabular}{lccc}
\hline & $\begin{array}{c}\text { No. of } \\
\text { determinations }\end{array}$ & Mean (range) (ng/ml) & $\begin{array}{c}\text { Coefficient of } \\
\text { variation }(\%)\end{array}$ \\
\hline (a) Precision & & - & $4 \cdot 3$ \\
$\quad$ Intra-assay variation & 50 & $121(105-150)$ & $9 \cdot 5$ \\
$\quad$ Inter-assay variation & 12 & $9 \cdot 7(8 \cdot 9-12 \cdot 2)$ & $9 \cdot 4$ \\
Sensitivity & 10 & & \\
(b) Precision & & - & $3 \cdot 7$ \\
$\quad$ Intra-assay variation & 50 & $219(190-240)$ & $8 \cdot 3$ \\
$\quad$ Inter-assay variation & 12 & $12 \cdot 5(12 \cdot 3-13 \cdot 1)$ & $3 \cdot 6$ \\
Sensitivity & 10 &
\end{tabular}

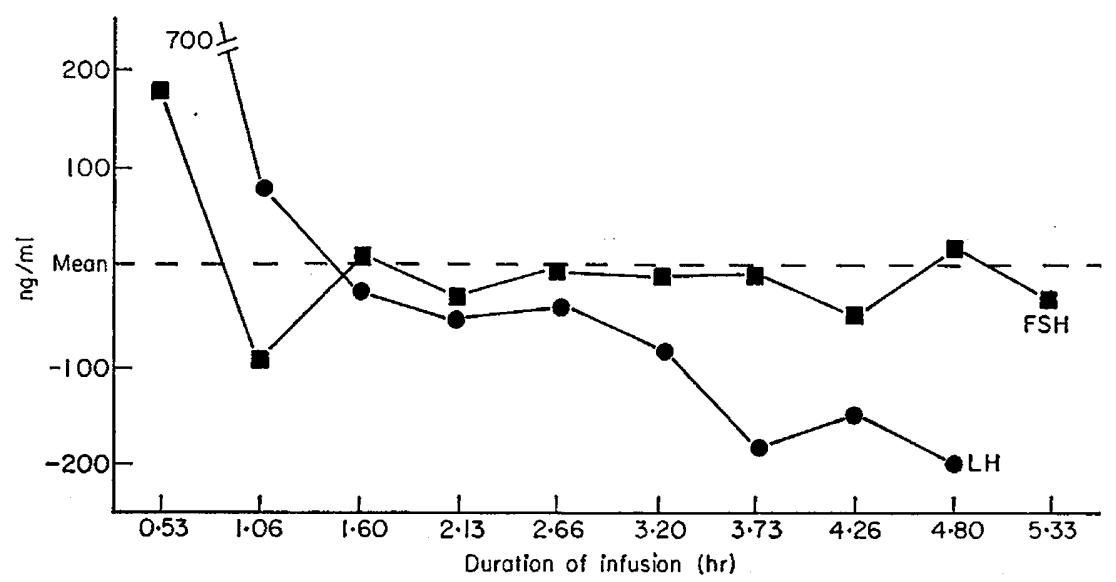

Text-fig. 2. The basal gonadotrophin levels (mean plus mean deviation from the mean) of LH and FSH during the course of six $4-5 \mathrm{hr}$ infusions with Krebs-Ringer bicarbonate buffer.

\section{Effect of Gn-RH}

A typical pattern of release for LH and FSH elicited by the repeated administration of $1 \mu \mathrm{g}$ $\mathrm{Gn}-\mathrm{RH} / \mathrm{ml}$ to the infusion system can be seen in Text-fig. 3. The areas below the curves for the release of LH and FSH were calculated by the method of the trapezoidal rule. Infusions of Gn-RH in the mass range of $250 \mathrm{ng}$ to $10 \mu \mathrm{g} / \mathrm{ml}$ produced a dose-response relationship, and the significance of the difference between these responses was determined by Student's $t$ test. The results are shown in Table 2.

Table 2. Results from the statistical analysis (Student's $t$ test) of the response areas of FSH and LH after administration of various quantities of $\mathrm{Gn}-\mathrm{RH}$

\begin{tabular}{rrrrrr}
\hline $\begin{array}{c}\text { Conc. Gn-RH/ml } \\
\text { medium }\end{array}$ & $\begin{array}{c}\text { FSH area response } \\
\text { (mean } \pm \text { SE) }\end{array}$ & Significance & $\begin{array}{c}\text { LH area response } \\
\text { (mean } \pm \text { SE) }\end{array}$ & Significance \\
\hline 1 & $250 \mathrm{ng}$ & $23 \pm 3.5(6)$ & & $28 \pm 3.5(16)$ & \\
2 & $500 \mathrm{ng}$ & $49 \pm 7.0(8)$ & $P<0.01$ versus 1 & $46 \pm 6.5(12)$ & $P<0.01 \quad$ versus 1 \\
3 & $1000 \mathrm{ng}$ & $44 \pm 8.2(9)$ & $P<0.05$ versus 1 & $49 \pm 5.0(15)$ & $P<0.0025$ versus 1 \\
& & & N.S. versus 2 & N.S. versus 2 \\
4 & $10 \mu \mathrm{g}$ & $63 \pm 6.0(2)$ & $P<0.0025$ versus 1 & $77 \pm 12.0(2)$ & $P<0.0005$ versus 1 \\
& & N.S. versus 2 & & $P<0.05$ versus 2 \\
& & N.S. versus 3 & & $P<0.05$ versus 3 \\
\hline
\end{tabular}

Figures in parentheses indicate the number of incubations. 


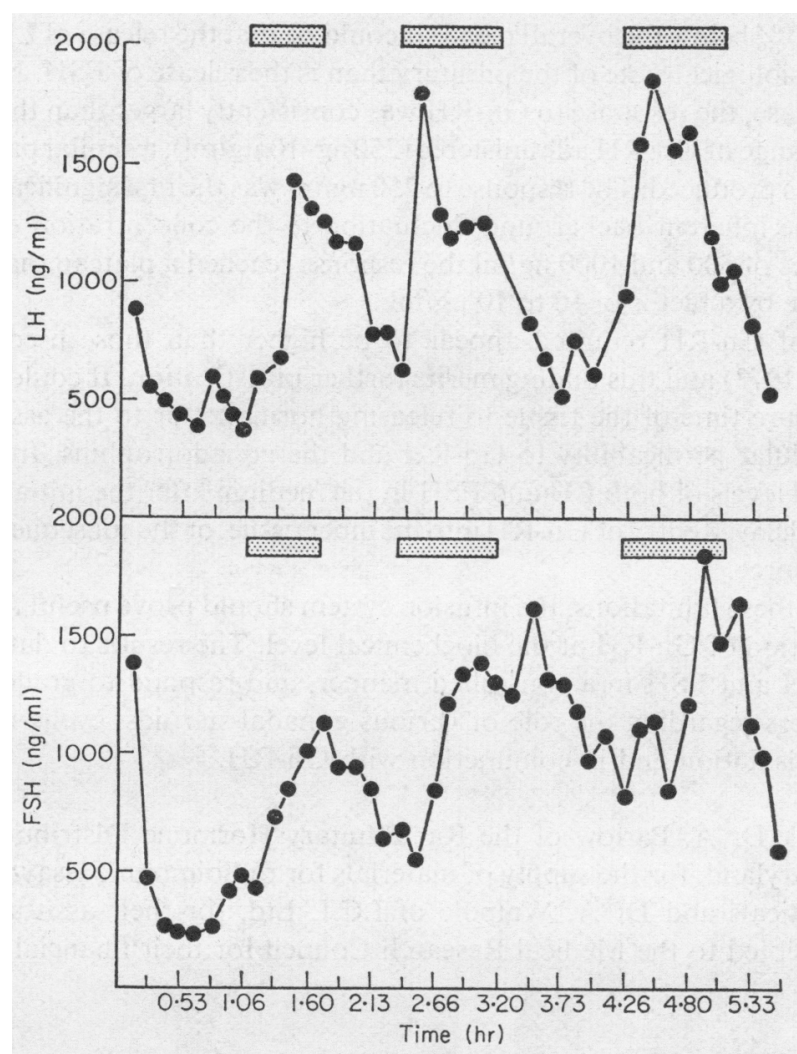

Text-fig. 3. The results obtained after assay of LH and FSH concentrations in the fractions collected after infusion of Gn-RH. The stippled bars represent the periods of Gn-RH infusion at $1 \mu \mathrm{g} / \mathrm{ml} \mathrm{medium}$.

\section{Discussion}

The pituitary infusion system reported by Serra \& Midgley (1970), has been developed to enable single or multigland incubations. The ability to keep up to four pituitaries in the same flask ensured that, even if one or two suffered damage or thermal shock during removal, there was sufficient active material remaining to produce a response to $\mathrm{Gn}-\mathrm{RH}$.

The volume of each aperture of the tissue retaining disc was chosen to approximate the volume of the rat anterior pituitary. This design ensured that the infusing medium passing through the incubation flask must pass over and around the enclosed tissue, thus removing the necessity for agitating the flasks.

It has been reported (Porter \& Smith, 1967) that the blood flow through the hypophysial portal vessels of an anaesthetized adult male rat ranges from $0.6-1.0 \mu \mathrm{l} / \mathrm{mg}$ tissue. Since the weight of the anterior pituitary varies from $7-12 \mathrm{mg}$, the total portal blood flow by computation is between $4 \cdot 2-12$ $\mu \mathrm{l} / \mathrm{min}$. Although only the outside of the gland was being infused with medium, it was found that too slow a flow rate caused very lengthy clearance times and prolonged incubation periods. The infusion rate was therefore increased to $250 \mu \mathrm{l} / \mathrm{min} /$ flask of four glands $(62.5 \mu \mathrm{l} / \mathrm{min} / \mathrm{gland})$.

The results obtained from the measurement of the basal release of LH and FSH appears to indicate that the pituitary tissue requires $1.0-1.6 \mathrm{hr}$ to equilibrate in the infusion medium. After an initial surge of FSH, possibly released from damaged pituitary cells, the tissue appears to stabilize at around $1 \mathrm{hr}$, and then recover slightly to maintain a relatively constant level of release for 5-6 hr. The pattern for the basal release of LH differs slightly. After a very large release of LH over the first hour, the mean level then falls gradually during the course of the infusion and at the end of about 
$5 \mathrm{hr}$ has dropped to $30 \%$ below the overall mean. It could be that the release of $\mathrm{LH}$ is a more sensitive parameter of the physiological state of the pituitary than is the release of FSH. Notwithstanding this overall fall in $\mathrm{LH}$ release, the response to Gn-RH was consistently larger than that for FSH.

Within the mass range of $\mathrm{Gn}-\mathrm{RH}$ administered $(250 \mathrm{ng}-10 \mu \mathrm{g} / \mathrm{ml})$, a similar pattern of response for both $\mathrm{LH}$ and FSH was produced. The response to $250 \mathrm{ng} / \mathrm{ml}$ was the first significant release that could be discerned from the inherent background fluctuation in the concentration of LH and FSH. At the intermediary doses of 500 and $1000 \mathrm{ng} / \mathrm{ml}$ the response reached a plateau that was only exceeded by increasing the dose by a factor of 10 to $10 \mu \mathrm{g} / \mathrm{ml}$.

The dose levels of Gn-RH required appear to be higher than those used for administration in vivo (Rippel et al., 1973) and this finding merits further investigation. It could be explained by the relatively brief exposure time of the tissue to releasing hormone, or to the associated problems of gland, tissue and cellular permeability to Gn-RH and the gonadotrophins. In this connection the elevation of the basal levels of both LH and FSH in the medium after the initial infusion of Gn-RH could reflect either a delayed entry of Gn-RHinto the inner tissue, or the subsequent release of gonadotrophins from this source.

Notwithstanding these limitations, the infusion system should prove useful for further studies on the mechanism of action of Gn-RH at the biochemical level. The results to date show that isolated pituitaries release LH and FSH in a controlled manner, and respond to graded doses of Gn-RH. Studies are in progress regarding the role of various gonadal steroids, cyclic nucleotides and prostaglandins, both in isolation and in conjunction with Gn-RH.

We wish to thank Dr A. Parlow of the Rat Pituitary Hormone Distribution Program of the N.I.H. Bethesda, Maryland, for the supply of materials for radioimmunoassay; and Dr W. Bogie of Hoechst Pharmaceuticals and Dr A. Walpole of I.C.I. Ltd, for their assistance and supplies of Gn-RH. We are indebted to the Medical Research Council for their financial support (Grant No. G971/777/C).

\section{References}

Hunter, W.M. \& GReEnwood, F.C. (1962) Preparation of iodine ${ }^{131}$ labelled human growth hormone of high specific activity. Nature, Lond. 194, 495-496.

MAKINo, M. (1973) Study on the intracellular mechanism of $\mathrm{LH}$ release in the anterior pituitary. $A m . J$. Obstet. Gynec. 115, 606-614.

ONdo, J.G., EsKay, R.L., Mical, R.S. \& Porter, J.C. (1973) Effect of synthetic LRF infused into a hypophysial portal vessel on gonadotropin release. Endocrinology 93, 205-209.

Porter, J.C. \& Smith, K.R. (1967) Collection of hypophysial stalk blood in rats. Endocrinology 81, 1182-1185.

RipPEL, R.H., Johnson, E.S., White, W.F., Fujino, M., YamazaKı, I. \& NAKaYama, R. (1973) Ovulating and LH-releasing activity of a highly potent analog of synthetic gonadotropin-releasing hormone. Endocrinology 93, 1449-1452.
Schally, A.V., Kastin, A.J. \& Arimura, A. (1972) FSH-releasing hormone and LH-releasing hormone. Vitams Horm. 30, 83-164.

Serra, G.B. \& Midgley, A.R., JR (1970) The in vitro release of $\mathrm{LH}$ during continuous superfusion of single rat anterior pituitary glands. Proc. Soc. exp. Biol. Med. 133, 1370-1374.

SMITH, P.M. \& FolLETT, B.K. (1971) Luteinizing hormone releasing factor in the quail hypothalamus. J. Endocr. 53, 131-138.

TaIT, S.A.S., TaIT, J.F., OKaMoto, M. \& Flood, C. (1967) Production of steroids by in vitro superfusion of endocrine tissue. I. Apparatus and a suitable analytical method for adrenal steroid output. Endocrinology 81, 1213-1225.

Zolman, J. \& Convey, E. (1972) Bovine pituitary LH and prolactin release during superfusion in vitro. Proc. Soc. exp. Biol. Med. 140, 194-198.

Received 14 February 1975 